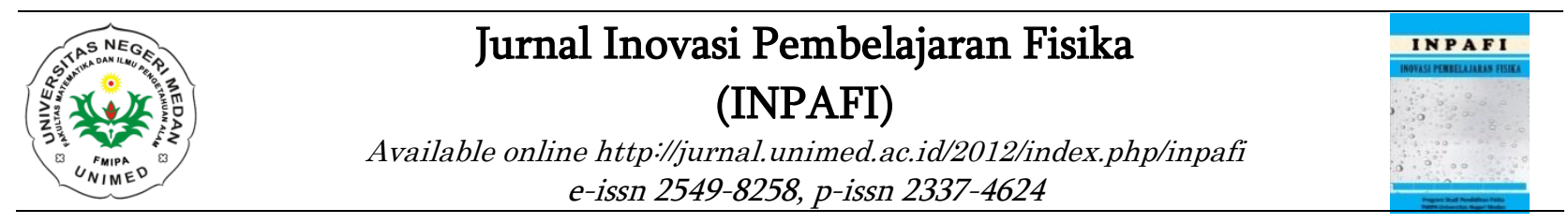

\title{
PENGARUH MODEL DISCOVERY LEARNING TERHADAP HASIL BELAJAR SISWA PADA MATERI POKOK FLUIDA STATIS DI KELAS XI SMA NEGERI 1 TANJUNG MORAWA T.P 2016/2017
}

\author{
Noprilita Hutabarat dan Henok Siagian \\ Jurusan Fisika FMIPA Universitas Negeri Medan \\ noprilita@mhs.unimed.ac.id
}

Diterima: Desember 2018. Disetujui: Januari 2019. Dipublikasikan: Februari 2019

\begin{abstract}
ABSTRAK
Penelitian ini bertujuan untuk mengetahui implementasi model Discovery Learning untuk meningkatkan hasil belajar fisika siswa pada materi Fluida Statis. Jenis penelitian ini adalah quasi eksperimen. Populasi dalam penelitian adalah seluruh siswa kelas XI IPA SMA Negeri 1 Tanjung Morawa T.P 2016/2017 yang terdiri dari 6 kelas. Pengambilan sampel dilakukan dengan cara cluster random sampling dengan mengambil 2 kelas yaitu kelas XI-IPA 5 sebagai kelas eksperimen dan kelas XI-IPA 6 sebagai kelas kontrol. Instrumen yang digunakan untuk mengetahui hasil belajar siswa adalah tes hasil belajar yang berbentuk pilihan ganda dengan jumlah 15 soal. Dari hasil penelitian diperoleh nilai rata-rata pretes kelas eksperimen 46,67 dan nilai rata-rata kelas kontrol 46,66. Nilai rata-rata postes hasil belajar siswa kelas eksperimen adalah 69,69 dan kelas konvensional adalah 53,33 . Hasil pengujian hipotesis thitung $=6,010$ dan tabel $=1,667$ sehingga thitung $>$ tabel maka ada pengaruh penerapan model Discovery Learning terhadap hasil belajar siswa.
\end{abstract}

Kata kunci : Discovery Learning, Hasil Belajar, dan Aktivitas Belajar.

\begin{abstract}
This study aims to determine the implementation of discovery learning model to improve student physics learning outcomens on static fluid material. This type of research is quasi experiment. The population in the study were all students of class XI IPA SMA Negeri 1 Tanjung Morawa consisting of 6 classes. Sampling is done by cluster random sampling by talking 2 classes of class XI-IPA 5 as experiment class and class XI-IPA 6 as control class. The instrument used to determine student learning outcomens is the test of learning result in the form of multiple choice with the number of 15 questions. From the result of research obtained the average value of experimental class postes 46,67 and the average value of control class 46,66 . The average score of postes of the students learning result of the experimental class is 69,69 and the control class is 53,33 . The result of the hypothesis testing thiting $=6,010$ and $t_{\text {tabel }}=1,667$ so thitung $>$ tabel then there is influence of applying of discovery learning model to result of student learning.
\end{abstract}

Keyword : Discovery Learning, learning outcomens, and learning activities 


\section{PENDAHULUAN}

Pendidikan merupakan pemegang peranan yang sangat penting bagi kelangsungan kehidupan manusia. Karena pada hakikatnya, melalui pendidikan Sumber Daya Manusia (SDM) yang berkualitas dicetak untuk menjadi motor penggerak kemajuan dan kemakmuran bangsa.

Salah satu permasalahan yang dihadapi oleh bangsa kita saat ini adalah masih rendahnya kualitas pendidikan pada setiap jenjang. Rendahnya pendidikan Indonesia dapat dilihat dari rendahnya hasil belajar siswa dalam berbagai mata pelajaran. Salah satu mata pelajaran yang memiliki nilai rendah adalah mata pelajaran fisika. Tujuan pembelajaran Fisika adalah terbentuknya kemampuan bernalar pada siswa yang tercermin melalui kemampuan berfikir logis, sistematis, empiris, rasional yang melibatkan proses dan mempunyai sikap objektif, jujur, disiplin dan ilmiah dalam memecahkan suatu permasalahan.

Namun pada kenyataan dilapangan belum sesuai yang diharapkan, selama proses pembelajaran fisika di kelas, banyak siswa yang kurang menyukai pelajaran fisika karena menganggap fisika itu menjenuhkan dan membosankan. Guru selalu menyajikan materi fisika dalam bentuk rumus-rumus dan perhitungan yang sulit yang membuat siswa sulit belajar. Aktivitas siswa juga masih kurang aktif, karena siswa jarang melakukan percobaan atau eksperimen yang dapat membuat siswa menjadi tidak aktif dan kreatif. Hal tersebutlah yang menyebabkan hasil belajar siswa rendah.

Berdasarkan hasil wawancara yang dilakukan peneliti dengan salah seorang guru fisika di SMA Negeri 1 Tanjung Morawa, hasil belajar fisika yang diperoleh oleh siswa masih tergolong rendah. Itu dibuktikan ketika dilihat dari nilai Kriteria Ketuntasan Minimal (KKM) yaitu 70, masih banyak siswa memperoleh nilai pada mata pelajaran fisika masih di bawah KKM. Dan juga berdasarkan instrumen lembar observasi yang diberikan peneliti kepada siswa, pelajaran fisika masih dianggap siswa sebagai pelajaran yang sulit dan membosankan. Dilihat dari hasil angket yang disebarkan kepada 38 orang siswa, 50 \% (19 orang siswa) berpendapat fisika itu sulit dipahami, $24 \%$ (9 orang siswa) berpendapat fisika biasa-biasa saja, dan hanya $26 \%$ (10 orang siswa) berpendapat fisika menarik dan menyenangkan. Walaupun sudah ada siswa yang nilai Fisikanya tuntas, tapi itu hanya beberapa siswa. Pada T.P. 2016/2017 semester I rata-rata nilainya $40 \%$ yang tidak tuntas KKM . Data ini menunjukkan bahwa nilai rata-rata ujian fisika kelas XI SMA Negeri 1 Tanjung Morawa T.P. 2016/2017 tersebut masih tergolong rendah.

Rendahnya nilai fisika siswa salah satunya dipengaruhi oleh model pembelajaran yang digunakan guru kurang bervariasi. Metode yang dominan digunakan guru adalah ceramah, tanya jawab, dan penugasan, dan siswa diarahkan untuk mencatat dan mengerjakan soal-soal, jarang siswa dihadapkan terhadap masalah-masalah yang kontekstual. Berdasarkan kenyataan tersebut, perlu diterapkan suatu model pembelajaran yang sesuai dan mampu meningkatkan aktivitas dan hasil belajar fisika siswa. Salah satu alternatif model pembelajaran yang memungkinkan diterapkan model pembelajaran yang berpusat pada siswa yaitu model Discovery Learning. Menurut peneliti Mubarok, C dan Sulistyo E. 2013 , Putrayasa, M, dkk dan Supriyanto, B terjadi peningkatan hasil belajar siswa.

Menurut Hosnan (2014) model Discovery Learning adalah suatu model penemuan, siswa didorong untuk belajar sebagian besar melalui 
Noprilita Hutabarat dan Henok Siagian; Pengaruh Model Discovery Learning Terhadap Hasil Belajar Siswa Pada Materi Pokok Fluida Statis Di Kelas XI SMA Negeri 1 Tanjung Morawa T.P 2016/2017

keterlibatan aktif mereka sendiri dengan konsep-konsep, prinsip-prinsip dan guru mendorong siswa untuk memiliki pengalaman melakukan percobaan yang memungkinkan mereka menemukan prinsip-prinsip untuk diri mereka sendiri. Perlu ditambahkan bahwa aktivitas belajar itu bersifat fisik maupun mental. Kegiatan belajar kedua aktivitas itu harus selalu berkait satu sama lain. Sehubungan dengan hal tersebut, Piaget menerangkan bahwa seorang anak itu berpikir sepanjang ia berbuat. Tanpa perbuatan berarti anak itu tidak berpikir. Oleh karena itu, agar anak berpikir sendiri maka harus diberi kesempatan untuk berbuat sendiri. Berpikir pada taraf verbal baru akan timbul setelah anak itu berpikir pada taraf perbuatan. Menurut hasil penelitian Winarni, dkk. 2016. Penerapan Model Discovery Learning Untuk Meningkatkan Oral Activities Siswa SMA adanya peningkatan disetiap aktivitas siswa.

Berdasarkan uraian di atas, maka peneliti berkeinginan untuk melakukan penelitian dengan judul "Pengaruh Model Discovery Learning Terhadap Hasil Belajar Siswa pada Materi Pokok Fluida Statis".

\section{METODE PENELITIAN}

Jenis penelitian ini adalah penelitian quasi experiment, yaitu penelitian yang bertujuan untuk mengetahui ada tidaknya pengaruh atau akibat dari sesuatu yang ditimbulkan pada subjek yaitu siswa.

Adapun langkah-langkah yang dilakukan dalam penelitian adalah :

1) Tahap pertama : melaksanakan pretes untuk mengetahui kemampuan awal siswa kelas sampel

2) Tahap kedua : Setelah melakukan pretes lalu dilakukanlah uji normalitas dan homogenitas pada data tes awal tersebut dan memilih kelas mana yang akan dijadikan kelas eksperimen dimana kelas eksperimen diberikan perlakuan dengan menggunakan model pembelajaran discovery learning Setelah tahap ini maka peneliti kembali memberikan postes kepada kelas eksperimen dan kelas kontrol untuk mengetahui kemampuan akhir (hasil belajar) siswa setelah diberikan perlakuan dan peneliti kembali menganalisis data hasil posttes kedua kelas tersebut.

\section{HASIL DAN PEMBAHASAN}

\section{a. Hasil Penelitian}

Hasil penelitian menunjukkan adanya pengaruh model Discovery Learning terhadap hasil belajar siswa pada materi pokok fluida statis. Hal ini dibuktikan dengan nilai post-tes hasil belajar di kelas eksperimen lebih unggul dari nilai post-tes hasil belajar siswa dikelas kontrol, yang sebelumnya sudah diketahui bahwa kelas eksperimen dan kelas kontrol memiliki kemampuan awal yang sama. Adapun perolehan hasil nilai rata-rata pre-test 46,66 dan post-tes 53,33 dikelas kontrol sedangkan dikelas eksperimen hasil nilai ratarata pre-tes 46,67 dan post-tes 69,69. Perhatikan gambar dibawah :

Tabel 1. Data Pretes Kelas Eksperimen

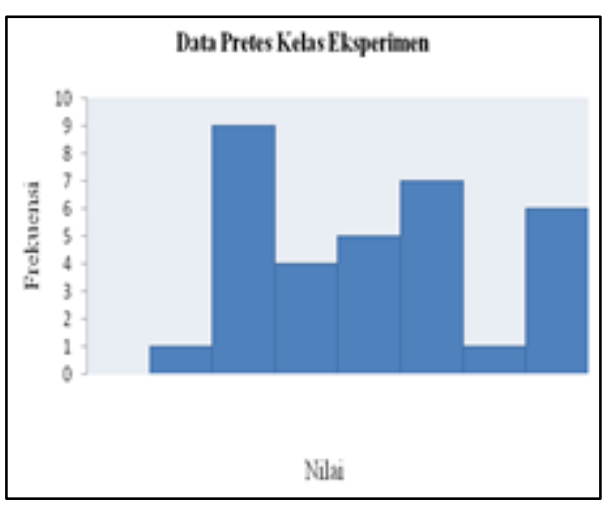

Tabel 2. Data Postes Kelas Eksperimen 


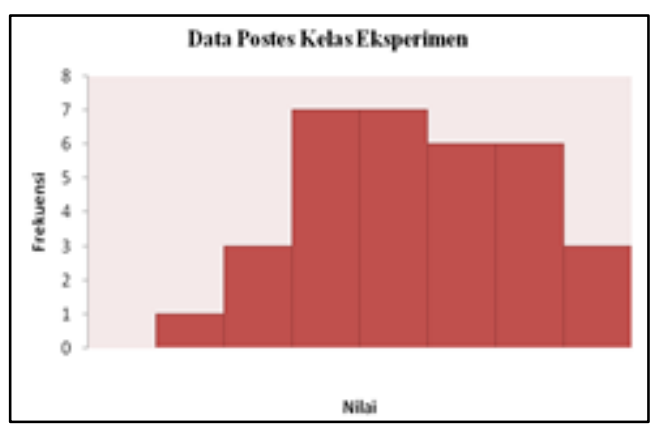

Tingginya hasil belajar siswa dikelas eksperimen dipengaruhi oleh model discovery learning melibatkan aktivitas yang lebih aktif, rasa ingin tahu siswa muncul. Ini dibuktikan dengan nilai rata-rata setiap aktivitas siswa. ditunjukkan pada tabel dibawah:

Tabel 3. Hasil Observasi Kelas

\begin{tabular}{|c|c|c|}
\hline No & Aktivitas & $\begin{array}{c}\text { Persentase } \\
\text { Nilai }\end{array}$ \\
\hline 1 & Stimulasi & $80,22 \%$ \\
\hline 2 & $\begin{array}{c}\text { Megidentifikasi } \\
\text { Masalah }\end{array}$ & $78,02 \%$ \\
\hline 3 & Pengumpulan Data & $70,70 \%$ \\
\hline 4 & Pengolahan Data & $62,62 \%$ \\
\hline 5 & Pembuktian & $67,41 \%$ \\
\hline 6 & Menyimpulkan & $77,01 \%$ \\
\hline
\end{tabular}

\section{b. Pembahasan}

Berdasarkan uji hipotesis yang dilakukan peneliti dengan menggunakan uji $t$ maka didapat hasil thitung $=6,010$ dan tabel 1,667. Karna harga thitung lebih besar dari harga tabel $(6,010>1,667)$. Rata-rata nilai yang dicapai siswa, pretes 46,67 dan postes 69,69 . Hal ini menunjukkan bahwa ada perbedaan yang signifikan akibat pengaruh model discovery learning terhadap hasil belajar siswa pada materi pokok Fluida statis di kelas XI semester
II SMA Negeri 1 Tanjung Morawa T.P. 2016/2017. Hal ini sesuai dengan hasil penelitian terdahulu penelitian Rusmawan (2014) penggunaan model discovery Learning dapat meningkatkan pemahaman konsep dan keterampilan terhadap hasil belajar. Berdasarkan gambar diagram batang kemampuan pretes dan postes kognitif siswa, ranah kognitif diantaranya Aplikasi ( $\left.\mathrm{C}_{3}\right)$, menganalisis $\left(\mathrm{C}_{4}\right)$, mengevaluasi $\left(\mathrm{C}_{5}\right)$ dan mencipta ( $\mathrm{C}_{6}$ ) diprediksi berdistribusi normal hal ini sejalan dengan hasil yang didapat peneliti sebelum menguji hipotesis menggunakan uji t bahwa data berdistribusi normal dan homogen. Berdasarkan gambar diagram batang kemampuan kognitif siswa $\mathrm{C}_{3}$ (18,72\%), C4 (18,61\%), C5 (13,86\%) dan $\mathrm{C}_{6}$ $(14,26 \%)$ sudah baik, karna grafik berbentuk linear ke kanan bawah, menunjukkan semakin tinggi tingkat soal, maka yang menjawab semakin sedikit. Tetapi berbeda dengan gambar diagram kognitif (Gambar 4.4), menunjukkan data tidak normal, perlu ada perbaikan. Juga soal ( $\mathrm{C}_{5}$ ) dan ( $\mathrm{C}_{6}$ ) yang digunakan pun tidak cocok, tidak menunjukkan adanya sebab akibat, perlu ada perbaikan, karena soal $\mathrm{C}_{5}$ dan $\mathrm{C}_{6}$ sama dengan soal $\mathrm{C}_{3}$ dan $\mathrm{C}_{4}$ masih bentuk perhitungan dan analisis. Hasil penelitian ini didukung oleh Elly Avida Saragih (2016). Pengaruh Model Pembelajaran Discovery Learning Terhadap Hasil Belajar Fisika Ditinjau dari Motivasi Belajar Pada Materi Elastisitas dan Hukum Hooke Siswa Kelas X SMA YPPK YOS SUDARSONO MERAUKE, dimana peneliti melihat hasil belajar melalui peningkatan ranah kognitif siswa.

Berdasarkan aspek aktivitas belajar persentase yang didapat siswa masih kurang baik, pada pengolahan data dan pembuktian. Pada aktivitas model discovery learning, pengolahan data $(62,62 \%)$ dan pembuktian $(67,41)$ kurang baik, sehingga peneliti belum sukses menjalankan model discovery learning. Hal ini disebabkan oleh siswa belum terbiasa diperhadapkan dalam memecahkan masalah, 
Noprilita Hutabarat dan Henok Siagian; Pengaruh Model Discovery Learning Terhadap Hasil Belajar Siswa Pada Materi Pokok Fluida Statis Di Kelas XI SMA Negeri 1 Tanjung Morawa T.P 2016/2017

siswa jarang di bawa ke lab sehingga hasil dari pengolahan data yang dilakukan siswa, belum menghasilkan konsep baru. Pada saat membuktikan hipotesis yang mereka buat, masih banyak mengalami kesalahan atau tidak sesuai dengan teori yang benar, argument yang diberikan siswa pun kurang jelas, tidak dapat dipertanggung jawabkan dan selama ini guru menyampaikan materi dalam bentuk final, tidak membiarkan siswa menemukan sendiri. Jadi perlu ada perbaikkan, dengan cara meningkatkan aktivitas siswa dan kesiapan peneliti dalam membawakan model discovery learning. Akan tetapi pada aspek aktivitas belajar dikelas, pada setiap pertemuannya mengalami peningkatan di setiap aktivitasnya sebesar 72,66\%. Hal ini sesuai dengan hasil penelitian Gina Rosarina (2016) dengan menggunakan model discovery Learning, Hasil belajar siswa mengalami peningkatan yang cukup baik pada setiap siklusnya Hal ini juga sesuai dengan hasil penelitian terdahulu Suprayanti. I. (2016) dimana peneliti melihat peningkatan aktivitas belajar berdasarkan model discovery learning, menurut pengolahan data dan pembuktian dan Hasil penelitian Istiana, Galuh dkk. 2013. Penerapan Model Pembelajaran Discovery Learning Untuk Meningkatkan Aktivitas Dan Prestasi Belajar Pokok Bahasan Larutan Penyangga Pada Siswa Kelas Xi Ipa Semester Ii Sma Negeri 1 Ngemplak Tahun Pelajaran 2013/2014.

Berdasarkan uji hipotesis ada perbedaan yang signifikan akibat pengaruh model discovery learning terhadap hasil belajar siswa pada materi Fluida Statis di kelas XI IPA Semester SMA Negeri 1 Tanjung Morawa T.P 2016/2017. Akan tetapi tidak didukung oleh proses pembelajaran yang berlangsung seperti aspek aktivitas. Dalam hal ini Uji t belum tentu benar, karena kontrol yang tidak tepat (variabel yang diamati tidak tepat).

\section{KESIMPULAN DAN SARAN}

\section{a. Kesimpulan}

Berdasarkan hasil analisis dan uji statistik serta pembahasan maka disimpulkan sebagai berikut :

1. Hasil belajar siswa dengan menggunakan model Discovery Learning pada materi pokok Fluida Statis kelas XI semester II SMA Negeri 1 Tanjung Morawa T.P 2016/2017 pada ranah kognitif memiliki nilai rata-rata pretes 46,67 dan postes 69,69 .

2. Hasil belajar siswa dengan menggunakan model Konvensional pada materi pokok Fluida Statis kelas XI semester II SMA Negeri 1 Tanjung Morawa T.P 2016/2017 pada ranah kognitif memiliki nilai rata-rata pretes 46,66 dan postes 57,1 .

3. Aktivitas belajar siswa yang mengikuti model Discovery Learning tiap pertemuannya mengalami peningkatan. Model Discovery Learning dapat mengembangkan keaktifan siswa dalam proses pembelajaran.

\section{b. Saran}

Berdasarkan hasil penelitian dan kesimpulan yang dikemukakan maka untuk tindak lanjut penelitian ini, peneliti mempunyai saran-saran sebagai berikut:

1. Kepada peneliti selanjutnya hendaknya membuat perencanaan yang lebih baik pada pengorganisasian kelompok, sebaiknya jumlah siswa dalam setiap kelompok cukup 4-5 orang saja.

2. Kepada peneliti selanjutnya sebaiknya memperhatikan pertanyaanpertanyaan yang akan diperhadapkan kepada siswa agar sesuai dengan peencapaian indicator yang diharapkan materi yang diteliti.

3. Kepada peneliti selanjutnya sebaiknya mencatat dan beri bimbingan kepada siswa 
yang pasif dan cenderung tidak mau melakukan apapun.

\section{DAFTAR PUSTAKA}

Istiana, Galuh dkk. 2013. Penerapan Model

Pembelajaran Discovery Learning Untuk Meningkatkan Aktivitas Dan

Prestasi Belajar Pokok Bahasan

Larutan Penyangga Pada Siswa Kelas

Xi Ipa Semester Ii Sma Negeri 1

Ngemplak Tahun Pelajaran

2013/2014. Jurnal Pendidikan Kimia

(JPK),Vol. 4 No. 2 Tahun 2015

Program Studi Pendidikan

KimiaUniversitasSebelasMaret

(http://jurnal.fkip.uns.ac.id/index.ph

$\mathrm{p} /$ kimia)

Hosnan. 2014. Pendekatan Saintifik dan

kontekstual dalam pembelajaran

Abad 21. Bogor: Ghalia Indonesia

Mubarok, C dan Sulistyo E. 2013. Penerapan

Model Pembelajaran Discovery Learning Terhadap Hasil Belajar Siswa Kelas X Tav Pada Standar Kompetensi Melakukan Instalasi Sound System Di Smk Negeri 2 Surabaya. Jurnal Pendidikan Teknik Elektro, Volume 03, Nomor 01,Tahun 2014, 215 -221

Putrayasa, M, dkk. Pengaruh Model Pembelajaran Discovery Learning Dan Minat Belajar Terhadap Hasil Belajar Ipa Siswa. Jurnal Mimbar PGSD Universitas Pendidikan Ganesha Jurusan PGSD (Vol: 2 No: 1 Tahun2014)

Rosarina, Gina, dkk . 2016. Penerapan Model Discovery Learning Untuk Meningkatkan Hasil Belajar Siswa Pada Materi Perubahan Wujud Benda. Jurnal Pena Ilmiah : Vol. 1
(2016)

Rusmawan, R. 2014. Penerapan Model Discovery Learning Berbasis Keterampilan Proses Untuk Meningkatkan Pemahaman Konsep dan Keterampilan Kerja Ilmiah Siswa SMA. Jurnal visi ilmu pendidikan 12 (1248-1260)

Saragih E Avida. 2016. Pengaruh Model Pembelajaran Discovery Learning Terhadap Hasil Belajar Fisika Ditinjau dari Motivasi Belajar Pada MateriElastisitas dan Hukum Hooke Siswa Kelas X SMA YPPK YOSSUDARSONO MERAUKE. Jurnal Ilmu Pendidikan Indonesia. Volume 4 Nomor 1, Edisi Februari 2016.

Supriyanto, B. Penerapan Discovery Learning Untuk Meningkatkan Hasil Belajar Siswa Kelas Vi B Mata Pelajaran Matematika Pokok BahasanKeliling Dan Luas Lingkaran Di Sdn Tanggul Wetan 02 KecamatanTanggul Kabupaten Jember. (P)ancaran, Vol. 3, No. 2, hal 165-174, Mei 2014.

Suprayanti, ida, dkk. 2016. Penerapan Model Discovery Learning Berbantuan Alat Peraga Sederhana Untuk Meningkatkan Aktivitas Dan Hasil Belajar Siswa Kelas VII SMPN 5 Jonggat tahun Pelajaran 2015/2016. Jurnal Pendidikan Fisika dan Teknologi (ISSN.24076902). Volume II No1, Januari 2016

Winarni, dkk. 2016. Penerapan Model Discovery Learning Untuk MeningkatkanOral Activities Siswa 
Noprilita Hutabarat dan Henok Siagian; Pengaruh Model Discovery Learning Terhadap Hasil Belajar Siswa Pada Materi Pokok Fluida Statis Di Kelas XI SMA Negeri 1 Tanjung Morawa T.P 2016/2017 $S M A$. Pendidikan Biologi FKIP UNS Surakarta, Indonesia. ISSN : 1693-265X Agustus 2016. 
Arends, R. I. 2008. Learning to Teach (Terjemahan Belajar untuk Mengajar). Yogyakata: Pustaka Pelajar.

Hamalik, O. 2003. Proses Belajar Mengajar. Jakarta: Bumi Aksara.

Manalu, Andriono. 2016. Efek Model Problem Based Learning Terhadap Kemampuan Pemecahan Masalah Siswa SMA Negeri 2 Pematang Siantar. Jurnal Inpafi. 4(2), 9198.

Simamora, P., dan Victorya, R. 2016. Penerapan Model Pembelajaran Berbasis Masalah pada Materi Suhu dan Kalor. Jurnal Pendidikan Indonesia. 5(2), 64-68.

Sitika, L. M., Muhardjito, dan Markus, D. 2015. Terhadap Kemampuan Pemecahan Masalah Fisika Ditinjau dari Kerja Ilmiah Siswa. Jurnal Universitas Negeri Malang. 6(1), 395-398.

Suyanto dan Jihad. 2013. Menjadi Guru Profesional, Strategi Meningkatkan Kualifikasi dan Kualitas Guru di Era Global. Jakarta: Esensi Erlangga Group.

Trianto. 2010. Mendesain Model Pembelajaran Inovatif-Progresif. Jakarta: Kencana.

Zunanda, M., dan Karya Sinulingga. 2015. Pengaruh Model Pembelajaran Berbasis Masalah dan Kemampuan Berpikir Kritis Terhadap Keterampilan Pemecahan Masalah Fisika Siswa SMK. Jurnal Pendidikan Fisika. 4(1), 63-70.

Trianto. 2010. Mendesain Model Pembelajaran Inovatif-Progresif. Jakarta: Kencana.

Suyanto dan Jihad. 2013. Menjadi Guru Profesional, Strategi Meningkatkan Kualifikasi dan Kualitas Guru di Era Global. Jakarta: Esensi Erlangga Group. 